\title{
Pengaruh Implementasi Desa Wisata Kampung Flory Kabupaten Sleman Terhadap Pendapatan Masyarakat
}

\author{
Anindya Sabila Maghriza ${ }^{1}$; Suswanta ${ }^{2}$ \\ ${ }^{1,2}$ Program Studi Ilmu Pemerintahan, Universitas Muhammadiyah Yogyakarta, \\ anindyarisa02@gmail.com
}

\begin{abstract}
Abstrak
Tujuan penelitian ini yaitu membahas dan memaparkan tentang pengaruh implementasi Kampung Flory Kabupaten Sleman terhadap pendapatan masyarakat. Peneliti menggunakan metode kualitatif dengan menganalisa data primer dan sekunder yang didapatkan. Adapun hasil dalam penelitian ini adalah implementasi Kampung Flory dalam meningkatkan pendapatan masyarakat dapat diukur dari: 1) Komunikasi berupa informasi mengenai keberadaan tempat wisata Kampung Flory, 2) Sumber daya adalah hal penting dalam implementasi sebab memberikan pengaruh terhadap pelaksanaan program yang terdapat dalam kebijakan, 3) Bentuk disposisi berupa penyediaan destinasi wisata oleh pihak pengelola yang diberikan terhadap masyarakat Kampung Flory, 4) Struktur birokrasi Kampung Flory, adanya campur tangan dari pihak pembantu guna menyokong perkembangan wisata Kampung Flory, dimulai dari pihak Pemerintah Desa, Pemerintah Kabupaten melalui Dinas Pariwisata, Dinas Pertanian, dan lembaga keuangan seperti Bank Indonesia dan Bank BPD DIY. Kampung Flory sebagai tempat wisata mandiri yang dikelola berdasarkan kemampuan sumber daya setempat oleh masyarakat sekitar dapat disimpulkan bahwa memberikan pengaruh terhadap pendapatan masyarakat berupa gaji dan upah yang diperoleh oleh masyarakat dari adanya pembayaran retribusi wisata Kampung Flory yang dibayarkan oleh pengunjung.
\end{abstract}

Kata kunci : Implementasi, Kampung Flory, Pendapatan Masyarakat

\begin{abstract}
The purpose of this study is to discuss and explain the effect of the implementation of Flory Village, Sleman Regency on people's income. Researchers used qualitative methods by analyzing the primary and secondary data obtained. The results in this study are the implementation of Kampung Flory in increasing people's incomes that can be measured from: 1) Communication in the form of information regarding the existence of tourist attractions in Kampung Flory, 2) Resources are important in implementation because they have an influence on the implementation of the programs contained in the policy, 3) The form of disposition in the form of providing tourist destinations by the manager is given to the people of Kampung Flory, 4) The bureaucratic structure of Flory Village, there is intervention from the assistants to support the development of Flory Village tourism, starting from the Village Government, Regency Government through the Tourism Office, Agriculture Service, and financial institutions such as Bank Indonesia and Bank BPD DIY, Village Implementation Flory as an independent tourist spot that is managed based on the ability of local resources by the surrounding community can be concluded that it has an influence on community income in the form of salaries and wages obtained by the community from the payment of Flory Village tourist retribution paid by visitors.
\end{abstract}

Keywords: Community Income, Flory Village, Implementation 


\section{Pendahuluan}

Industri pariwisata merupakan salah satu sarana yang tepat untuk meningkatkan pertumbuhan ekonomi masyarakat baik lokal maupun global. Pariwisata mempunyai dampak dan manfaat yang banyak, diantaranya menghasilkan devisa negara dan memperluas lapangan kerja (Sinonsayang \& Minahasa, 2018). Sektor pariwisata juga bertujuan untuk menjaga kelestarian alam dan mengembangkan budaya lokal (Ekp et al., 2020). Pentingnya peranan pariwisata dalam pembangunan ekonomi di berbagai negara sudah tidak diragukan lagi. Banyak negara sejak beberapa tahun terakhir menggarap pariwisata dengan serius dan menjadikan pariwisata sebagai sektor unggulan dalam perolehan devisa, penciptaan lapangan kerja, maupun pengentasan kemiskinan (Dritasto \& Anggraeni, 2013).

Penerapan pariwisata secara berkelanjutan diharapkan membawa dampak positif terhadap lingkungan, sosial dan budaya maupun pada ekonomi masyarakat lokal. Dalam pariwisata yang berkelanjutan, komunitas masyarakat menjadi titik tumpu yang sangat berpengaruh sebagai subjek dalam pembangunan yang berpartisipasi langsung pada pelaksanaan pariwisata berkelanjutan tersebut (Setijawan, 2018). Berbagai program pembangunan dan pemberdayaan masyarakat yang dilakukan baik melalui kebijakan nasional maupun daerah berupaya untuk menjadikan masyarakat diberdayakan sehingga meningkatkan pendapatan masyarakat (Ilmu \& Ratulangi, 2014). Adapun model pengembangan pariwisata yang sesuai untuk diterapkan dalam pariwisata berkelanjutan ialah model pengembangan pariwisata berbasis masyarakat (Community Based Tourism Development) (Pastor, 2019). Dalam model ini, dibutuhkan adanya partisipasi masyarakat secara langsung, karena dengan adanya partisipasi masyarakat, diharapkan pengembangan wisata berjalan lebih efektif dan masyarakat memiliki kontribusi dalam proses pembangunan secara langsung sehingga masyarakat dapat mandiri dan berdaya kedepan.

Indonesia sendiri memiliki banyak potensi dalam mengembangkan pariwisata baik itu berbasis alam, budaya maupun buatan. Perkembangan industri kepariwisataan saat ini membuat stakeholder terus bergerak dalam pembangunan 
pariwisata untuk meningkatkan kualitas dan kuantitas pariwisata serta jumlah wisatawan, baik nusantara maupun mancanegara (Pantai et al., 2018). Upaya Pemerintah Indonesia untuk pemerataan kesejahteraan ekonomi masyarakat diwujudkan melalui program Nawacita Jilid II periode Jokowi-Ma'ruf Amin yang bertujuan untuk pemerataan kesejahteraan ekonomi masyarakat, yang salah salah satunya berbasis peningkatan SDM. Peningkatan SDM diwujudkan melalui kemandirian desa yang mengarah pada desa wisata, sehingga dapat memberdayakan masyarakat desa sekaligus meningkatkan kualitas kehidupan, serta dapat mewujudkan kemandirian dalam sektor ekonomi (Hidayatulah \& Riau, 2018). Desa wisata merupakan salah satu bentuk penerapan pembangunan pariwisata berbasis masyarakat dan berkelanjutan. Melalui pengembangan desa wisata, diharapkan terjadi pemerataan yang sesuai dengan konsep pembangunan pariwisata yang berkesinambungan. Di samping itu, keberadaan desa wisata menjadikan produk wisata lebih bernilai budaya pedesaan, sehingga pengembangan desa wisata menjadi bernilai budaya tanpa merusaknya (Soleman \& Noer, 2017). Dimasa kini, desa wisata juga muncul sebagai solusi atas kekhawatiran terhadap wisata konvensional yang cenderung mengejar keuntungan ekonomi dan mengabaikan aspek sosial serta kelestarian lingkungan (Yasa \& Bagiana, 2015).

Daerah Istimewa Yogyakarta sebagai salah satu daerah yang letaknya berdekatan dengan Gunung Api Merapi (Ni et al., 2020), yang mana letusan Gunung Merapi memberikan limpahan yang luar biasa untuk lahan pertanian berupa lahan yang subur. Kondisi lingkungan ini menjadikan kawasan DIY memiliki berbagai macam wisata alam yang ditawarkan kepada wisatawan, seperti desa wisata, ekowisata, taman nasional dan agrowisata (Rani et al., 2018). Agrowisata di DIY sudah mengalami perkembangan yang sangat baik (Pertiwi, 2018). Banyak dari agrowisata yang kemudian mengangkat ciri khas tanaman dari daerah masing-masing, salah satu agrowisata yang sudah berkembang dengan baik adalah Agrowisata Kampung Flory (Ni et al., 2020).

Kampung Flory yang terletak di Desa Tridadi, Kecamatan Sleman, Kabupaten Sleman, DIY adalah branding dari agrowisata yang dikelola oleh kelompok masyarakat Desa Tridadi. Kampung Flory mulai dikembangkan pada 
tahun 2015 oleh masyarakat sekitar dengan nama Kampung Flory yang berasal dari nama bunga yaitu "flory". Kampung Flory awalnya merupakan tempat untuk mengembangkan tanaman hias dan tanaman buah untuk dijual langsung kepada pengunjung. Pengunjung yang datang kemudian banyak memberikan masukan kepada Kampung Flory, salah satunya yaitu untuk mengembangkan aktivitas wisata seperti outbond, wisata edukasi dan wisata kuliner. Luas lahan yang digunakan untuk membangun Kampung Flory yaitu sebesar 2 hektar yang berasal dari lahan milik kas desa yang disewa oleh pengelola dengan biaya 20 juta per tahunnya.

Kampung Flory memiliki tiga bagian divisi obyek wisata yang memiliki manajemen pengelolaan yang berbeda-beda, yaitu pertama Taruna Tani, sebagai divisi tanaman dan kuliner yang terdiri atas berbagai aktivitas wisata seperti showroom tanaman, pelatihan atau kunjungan edukasi, kolam bermain anak, greenhouse produksi tanaman dan kuliner iwak kalen. Kedua Desa Wisata Flory, sebagai wisata edukasi dan outbound, yang terdiri atas berbagai fasilitas seperti outbound dewasa, anak-anak dan wisata edukasi, gerai souvenir dan oleh-oleh, tour village kampung ndeso, family camp, hutan mini dan homestay. Ketiga ada Bali Ndeso, sebagai penyedia wisata kuliner berbentuk resto yang terdiri atas kuliner kopi kecah, spot selfie, kolam keceh mandi bola, mancing ikan, sepeda ontel atau gerobak sapi, menjamur, wisata edukasi belajar bahasa jawa, dolan ndeso dan meeting room.

Selain itu, Kampung Flory juga mengembangkan produk taninya menjadi wisata agro yang ada di kawasan Kabupaten Sleman. Keunikan yang dimiliki Kampung Flory yaitu menawarkan bentuk wisata back to nature untuk merasakan kehidupan di alam serta menyatu dengan alam (Karyani, 2020). Kampung Flory juga mencoba untuk menggabungkan agrowisata, wisata budaya dan ecotourism dalam satu kawasan desa wisata untuk lebih menarik pengunjung (Ramdani \& Karyani, 2020). Pada tahun 2019 Desa Wisata Kampung Flory menjadi juara 3 untuk kategori ekowisata terpopuler.

Jika pada penelitian-penelitian sebelumnya banyak yang berfokus pada pengembangan desa wisata melalui pemberdayaan masyarakat, seperti penelitian yang dilakukan oleh (Helmita et al., 2021) terkait pengembangan desa wisata 
berkonsep smart tourism melalui pemberdayaan masyarakat Desa Pujorahayu, kemudian penelitian yang dilakukan oleh (Sutiyono, 2008) dan (Kusniawati et al., 2017) yang membahas tentang pemberdayaan masyarakat dalam pelaksanaan program desa wisata di DIY dan di desa Bumiaji, maka penelitian ini lebih berfokus pada bagaimana pengaruh implementasi desa wisata terhadap pendapatan masyarakat desa, dengan mengambil objek penelitian Desa Wisata Kampung Flory di Desa Tridadi. Penelitian ini menjadi penting untuk dilakukan mengingat salah satu tujuan dibentuk dan dikembangkannya desa wisata adalah untuk memajukan desa dan kesejahteraan masyarakat, selain itu penelitian mengenai pengaruh implementasi desa wisata terhadap pendapatan masyarakat lokal juga sebagai salah satu upaya kontrol implementasi program berbasis kepariwisataan (Sukmadewi et al., 2019).

\section{Metode}

Penelitian dilakukan di Desa Wisata Kampung Flory, Desa Tridadi, Kecamatan Sleman, Kabupaten Sleman, Daerah Istimewa Yogyakarta, dengan menggunakan pendekatan deskriptif kualitatif. Penelitian kualitatif digunakan untuk menemukan sekaligus mengumpulkan jawaban dari narasumber atau responden untuk menjawab permasalahan-permasalahan yang sedang diteliti (Subandi, 2011). Kemudian, data-data yang telah diperoleh, dideskripsikan untuk memperjelas jawaban atas permasalahan agar mempermudah pembaca dalam memahami hasil penelitian (Gumilang, 2016). Data penelitian berasal dari hasil wawancara, observasi, dan dokumentasi terhadap beberapa narasumber seperti pengelola dan masyarakat di Desa Wisata Kampung Flory serta wisatawan. Dari data yang diperoleh, kemudian dilakukan analisis data dengan tahapan reduksi data, penyajian data, dan juga penarikan kesimpulan ( Moleong, 2017; Sudirman et al., 2021; Sudirman \& Rifai, 2021).

\section{Hasil dan Pembahasan}

Untuk membahas dan menganalisis pengaruh implementasi Kampung Flory Kabupaten Sleman terhadap pendapatan masyarakat desa, digunakan teori 
implementasi dari George Edward III yang menjelaskan bahwasannya implementasi dari suatu program memiliki empat tolok ukur, yakni: 1) Komunikasi, 2) Sumber daya, 3) Disposisi, dan 4) Struktur birokrasi, sedangkan pengukuran pendapatan masyarakat memiliki beberapa tolok ukur yaitu: 1) Gaji dan upah, 2) Sewa:

\section{Implementasi Program Desa Wisata Kampung Flory Kabupaten Sleman a. Komunikasi}

Dalam implementasi Kampung Flory sebagai salah satu program yang bertujuan untuk menambah pendapatan masyarakat desa, dibutuhkan suatu komunikasi yang dilaksanakan oleh pihak penyelenggara program terhadap pihak lain untuk mempromosikan keberadaan Kampung Flory sebagai tempat wisata di Kabupaten Sleman. Dengan adanya komunikasi yang baik maka akan meningkatkan jumlah pengunjung yang datang ke Kampung Flory, sehingga secara tidak langsung mampu meningkatkan pemasukan Kampung Flory dan masyarakat desa yang bekerja pada pengelolaan Kampung Flory.

Komunikasi oleh Kampung Flory dilakukan dengan memberikan informasi melalui Travel Dialog yang dilaksanakan oleh Bidang Pemasaran Dinas Pariwisata Kabupaten Sleman untuk memasarkan fasilitas, sarana dan prasarana Kampung Flory. Kegiatan Travel Dialog dilaksanakan secara rutin untuk menarik wisatawan agar mengunjungi Kampung Flory, serta dilakukan kerjasama antara Pemerintah Kabupaten Sleman dan Dinas Pariwisata Kabupaten Sleman dengan pihak sekolah menengah yang ada di seluruh Pulau Jawa. Pemasaran Kampung Flory sebagai tempat wisata juga dilakukan melalui website wisata seperti travelspromo.com dan digitiket.com.

Keberadaan informasi mengenai Kampung Flory di internet mampu menarik perhatian wisatawan untuk berkunjung dan memberikan keuntungan tidak hanya bagi pemilik website wisata karena Kampung Flory telah mengiklankan wisatanya, tetapi juga untuk para wisatawan karena tersedianya informasi bagi calon pengunjung yang belum pernah mengunjungi tempat wisata tersebut, sebab terdapat rincian berupa alokasi harga yang perlu disiapkan oleh wisatawan dan pemaparan mengenai sarana dan prasarana Kampung Flory. Banyaknya wisatawan 
yang mengunjungi Kampung Flory juga berdampak baik pada bertambahnya pendapatan masyarakat desa di sekitar Kampung Flory.

\section{Gambar 1. Pemasaran melalui Website Wisata}

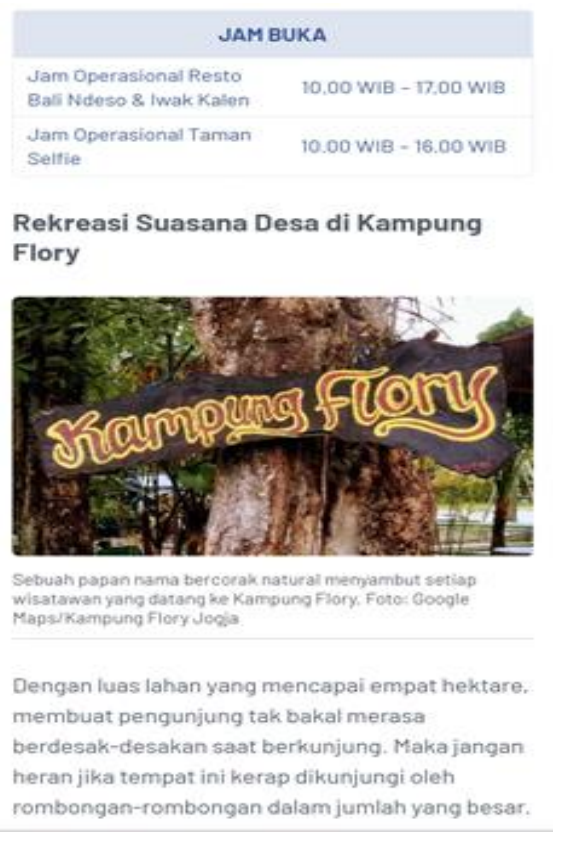

Sumber: travelspromo.com (2020)

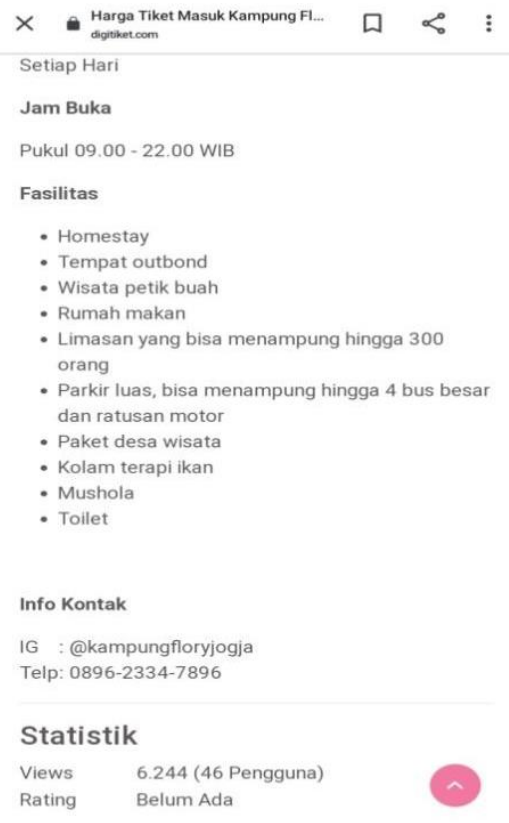

Sumber: digitiket.com (2020)

\section{b. Sumber Daya}

Pelaksanaan kegiatan di Desa Wisata Kampung Flory tidak terlepas dari tenaga kerja yang bekerja sama untuk saling mengembangkan potensi wisata setempat melalui kemampuan yang dimiliki oleh setiap sumber daya manusia. Pemerintah Kabupaten Sleman juga melakukan pendekatan swadaya masyarakat guna mewujudkan kemandirian dengan memanfaatkan modal sosial, sehingga menciptakan sinergi antara pemerintah dengan masyarakat. Pengembangan wisata Kampung Flory yang dilaksanakan oleh masyarakat juga menuntun masyarakat untuk bertindak secara positif terhadap kondisi lingkungannya, yang kemudian berpengaruh pada mata pencaharian. Tidak hanya pengaruh terhadap sumber daya manusia sekitar, adanya pihak lokal sebagai bagian dari pengembangan wisata mampu meningkatkan eksistensi tempat wisata. Pengelolaan Kampung Flory dibagi menjadi tiga bagian, yakni: 1) Divisi Taruna Tani sebagai pengelola kuliner 
dan tani, 2) Desa Wisata Flory sebagai pengelola rekreasi alam, dan 3) Bali Ndeso sebagai pengelola resto atau tempat kuliner yang ada di Kampung Flory.

Dilansir dari laman resmi Berita Surabaya Net, melalui pengelolaan yang dilakukan oleh sumber daya manusia setempat terhadap pengembangan Kampung Flory, diketahui pada tahun 2018 telah mencapai pemasukan sekitar Rp 1.000.000.000 sedangkan ditahun 2019 mengalami peningkatan mencapai angka Rp 1.200.000.000. Kenaikan pendapatan Kampung Flory merupakan bentuk partisipasi dan kinerja yang baik dari masyarakat dalam mengembangkan potensi wisata Kampung Flory. Pihak manajemen Kampung Flory yakni Bapak Sudiharditono menjelaskan jika pendapatan dengan jumlah yang tinggi juga harus disalurkan kepada Desa Tridadi sebagai pemilik lahan di Kampung Flory serta masyarakat yang telah bekerja keras dalam pengelolaan Kampung Flory. Berikut ini data mengenai jumlah masyarakat yang bekerja di Kampung Flory:

Tabel 1. Jumlah Tenaga Kerja di Kampung Flory

\begin{tabular}{|l|c|}
\hline \multicolumn{1}{|c|}{ Divisi } & Jumlah Tenaga Kerja \\
\hline Taruna Tani Flory & 8 Orang \\
\hline Desa Wisata & 16 Orang \\
\hline Resto Bali Ndeso & 40 Orang \\
\hline Jumlah & 64 Orang \\
\hline
\end{tabular}

Sumber: Diolah dari hasil wawancara (2020)

Dari tabel di atas, diketahui bahwa jumlah tenaga kerja di Kampung Flory berjumlah 64 orang yang berasal dari masyarakat sekitar. Pengadaan sumber daya masyarakat sekitar sebagai tenaga kerja di Kampung Flory secara tidak langsung telah mengimplementasikan regulasi pemerintah untuk mengembangkan industri ekonomi kreatif yang tertuang pada Instruksi Presiden RI Nomor 6 Tahun 2009 yang menjelaskan bahwa dalam pengembangan bisnis kreatif dapat dilaksanakan oleh masyarakat lokal guna meningkatkan kemampuan dan pemasukan. Dengan demikian, Kampung Flory telah melaksanakan kebijakan dan eksploitasi kreasi oleh masyarakat lokal untuk mengembangkan potensi alam menjadi daya tarik wisata.

Masyarakat yang bekerja untuk Kampung Flory juga memperoleh gaji sesuai aturan UMR yang berlaku. Apabila dikaitkan dengan indikator pendapatan 
masyarakat yaitu gaji dan upah tenaga kerja lokal di Kampung Flory yang mencapai tingkat UMR, maka pihak pengelola wisata telah melaksanakan tujuan dari pariwisata terhadap masyarakat yakni berupa penyediaan lapangan kerja guna meningkatkan pemasukan masyarakat. Hal ini sejalan dengan salah satu keuntungan dari pariwisata, yaitu memberikan peluang besar bagi pendapatan masyarakat sebagai tenaga kerja lokal.

Pengembangan tempat wisata menjadi salah satu pengembangan sumber daya berupa destinasi yang terdapat pada tempat wisata sebagai suatu objek pariwisata yang dapat dinikmati oleh pengunjung dan fasilitas sebagai penunjang perjalanan wisata. Dari beberapa objek wisata yang ada di Kampung Flory, pengelola membuat paket wisata untuk mempermudah wisatawan memilih wisata yang disukai dan dapat menyesuaikan dengan alokasi dana pribadi. Berikut rincian dana paket wisata Kampung Flory:

Tabel 2. Rincian Paket Wisata Kampung Flory

\begin{tabular}{|c|c|c|}
\hline \multicolumn{3}{|c|}{ Paket Edukasi } \\
\hline $\begin{array}{c}\text { Paket A } \\
\text { Tanaman (Rp.30.000,-) }\end{array}$ & $\begin{array}{c}\text { Paket B } \\
\text { Seni (Rp.30.000,-) }\end{array}$ & $\begin{array}{c}\text { Paket C } \\
\text { Kelas Memasak (Rp.30.000,-) }\end{array}$ \\
$\begin{array}{c}\text { Pengenalan Alat dan } \\
\text { Pupuk Pertanian }\end{array}$ & Ice Breaking & $\begin{array}{c}\text { Membuat Makanan } \\
\text { Tradisional }\end{array}$ \\
\hline Bercocok Tanam & Lukis Gerabah & Fun Games \\
\hline Mini Trip & Membuat Pin Flory & Mini Trip \\
\hline \multicolumn{3}{|c|}{ Paket Outbound } \\
\hline $\begin{array}{c}\text { Paket Flory Man } \\
\text { (Rp.60.000,-) }\end{array}$ & $\begin{array}{c}\text { Paket Flory Kids } \\
\text { (Rp.45.000,-) }\end{array}$ & $\begin{array}{c}\text { Paket Flory HUMI } \\
\text { (Rp.35.000,-) }\end{array}$ \\
\hline Ice Breaking & Ice Breaking & Wahana High Rope \\
\hline Fun Games & Fun Games & Outbound Flying Fox \\
\hline Wahana Air 1 dan & Repotting Tanaman & Fun Games \\
Wahana Air 2 & Wahana Kering, & \\
\cline { 1 - 2 } Permainan Kolam Besar & Wahana Air 1, dan & \\
\hline Mini Trip & Wahana Air 2 & \\
\hline Terapi Ikan & Mini Trip & \\
\hline Seluncur Air & Terapi Ikan & \\
\cline { 1 - 2 } Sunbap Ikan &
\end{tabular}

Sumber: Diolah dari hasil wawancara (2020)

Berdasarkan tabel di atas, dapat diketahui jika unsur penyokong sumber daya pada suatu tempat wisata ialah dengan adanya objek wisata yang dapat dijadikan sebagai pusat kunjungan bagi masyarakat, terlebih jika terdapat beberapa 
pilihan objek yang dapat dicoba oleh wisatawan, hal ini dapat menjadi nilai tambah dari tempat wisata tersebut. Selain objek wisata yang menjadi bagian dari sumber daya, ada pula fasilitas sebagai sarana dan prasarana yang dibutuhkan wisatawan saat berkunjung ke Kampung Flory. Adapun beberapa fasilitas tersebut ialah:

Tabel 3. Fasilitas di Kampung Flory

\begin{tabular}{|l|c|}
\hline \multicolumn{1}{|c|}{ Fasilitas } & Jumlah \\
\hline Pusat Informasi & 1 \\
\hline Penginapan & 2 \\
\hline Tempat makan & 3 \\
\hline Toko Oleh-Oleh & 1 \\
\hline Musholla & 2 \\
\hline Kamar Mandi & 15 \\
\hline Tempat Parkir & 3 \\
\hline Pos Keamanan & 2 \\
\hline Pos Kesehatan & 1 \\
\hline Saung & 4 \\
\hline
\end{tabular}

Sumber: Diolah dari hasil wawancara (2020)

Adanya fasilitas berupa sarana dan prasarana yang memadai merupakan langkah penting dalam mencapai realisasi pengembangan pariwisata agar mencapai tujuan dan sasaran seperti yang diharapkan saat pembentukkan tempat wisata tersebut, karena dengan fasilitas yang memadai maka dapat menjadi nilai tambah bagi tempat wisata, sehingga dapat menarik lebih banyak pengunjung untuk datang.

Pada indikator sumber daya ini, diketahui jika implementasi Kampung Flory sebagai bentuk sumber pendapatan masyarakat desa Tridadi sudah berjalan dengan baik. Menurut Edward III, sumber daya adalah hal penting dalam implementasi sebab memberikan pengaruh terhadap pelaksanaan program yang terdapat dalam kebijakan sebelumnya, berikut merupakan bukti pengaruh sumber daya sebagai bagian dari tolok ukur implementasi: 1) Pegawai atau tenaga kerja (SDM) yang terdapat di Kampung Flory, 2) Sistematika pelaksanaan kebijakan oleh implementor, 3) Otoritas implementor yang diwujudkan dengan adanya wewenang masyarakat sebagai pengelola dan tenaga kerja lokal di Kampung Flory, 4) Daya pendukung berupa fasilitas serta sarana dan prasarana sebagai penunjang implementasi Kampung Flory sebagai tempat wisata yang mempengaruhi pendapatan masyarakat. Adapun hubungan yang ditemukan dari adanya fasilitas berupa sarana dan prasarana terhadap pendapatan masyarakat bahwa semakin 
terpenuhinya fasilitas tersebut maka akan menarik jumlah pengunjung untuk berwisata ke Kampung Flory, apabila pengunjung meningkat maka pendapatan masyarakat selaku tenaga kerja lokal pun turut bertambah.

\section{c. Disposisi}

Disposisi diartikan sebagai karakteristik dan tindakan dari implementator atau pelaksana. Karakteristik dan tindakan yang berperan dalam Kampung Flory ini mencakup pengelolaan Kampung Flory yang dilakukan oleh anggota yang berjumlah 30 orang. Adapun tindakan yang dilaksanakan ialah membentuk UMKM dan Koperasi berupa penjualan tanaman hias dan kuliner, serta menyediakan destinasi wisata di Kampung Flory. Penyediaan destinasi wisata oleh pihak pengelola bersama masyarakat Kampung Flory ialah suatu bentuk disposisi yang telah terlaksana sebab telah memberikan demokratisasi kepada masyarakat berupa pemberian kesempatan agar dapat menuangkan ide dan inovasi yang mampu menghasilkan penambahan pendapatan masyarakat lokal. Disposisi dalam implementasi Kampung Flory sebagai tempat wisata yang menguntungkan tidak hanya dilaksanakan oleh masyarakat serta pengelola resmi saja, akan tetapi terdapat pula campur tangan dari beberapa pihak, yakni dinas pertanian, dinas pariwisata, dan pemerintah kabupaten Sleman.

Sebagai implementor dari pengadaan Kampung Flory, pihak Dinas Pertanian melaksanakan kebijakan yang diwujudkan melalui Program Green House sebagai tempat budidaya tanaman hias Aglonema dan Anggrek untuk masyarakat. Untuk mendukung implementasi kegiatan, pihak Dinas Pertanian juga memberikan pembekalan untuk masyarakat sekitar mengenai sistem budidaya dan penjualan tanaman tersebut agar suatu saat mampu dilanjutkan dan dikembangkan oleh masyarakat sehingga memperoleh penghasilan seperti yang diharapkan. Dinas Pertanian juga ikut serta dalam pembentukan kelompok Taruna Tani yang bertujuan untuk meningkatkan produktivitas petani melalui teknis perawatan dan pemeliharaan tanaman hias di Kampung Flory yang beranggotakan 15 orang. Disposisi yang telah dilaksanakan oleh pihak Dinas Pertanian ini cenderung pada peranan suatu instansi dalam mendukung kebijakan dan program yang terdapat pada suatu tempat wisata dengan melakukan berbagai tindak nyata sehingga 
terbentuk suatu keadaan sosial yang mendapatkan manfaat dari partisipasi instansi tersebut.

Bentuk disposisi Dinas Pariwisata dapat dilihat dari adanya pengembangan objek wisata dalam bentuk koordinasi dengan wujud peraturan dan pembentukan konsep kegiatan yang terdapat di Kampung Flory melalui pemasaran di beberapa media elektronik guna meningkatkan jumlah wisatawan. Selain itu, Dinas Pariwisata juga berfungsi sebagai pihak yang menstimulasi dan memenuhi fasilitas wisata di Kampung Flory. Dinas Pariwisata memerlukan kesiapan yang cukup dan memadai untuk mengelola dan meningkatkan potensi wisata sebab pihak tersebut merupakan koordinator sekaligus stimulator dan fasilitator pariwisata yang ada di Kabupaten Sleman.

Disposisi oleh Pemerintah Kabupaten Sleman dapat dilihat dari adanya kesiapan dan upaya berupa tindakan Pemerintah Kabupaten Sleman dalam mengimplementasikan kebijakan pariwisata sektor pertanian atau agrowisata seperti yang telah dituangkan dalam Peraturan Gubernur Nomor 43 Tahun 2016 mengenai pengembangan wisata yang bergerak pada sektor pertanian. Adapun strategi yang digunakan Pemerintah Kabupaten Sleman dalam disposisinya ialah melalui perencanaan dan pengembangan destinasi wisata dan sarana prasarana agar potensi dan sumber daya lebih kuat dari sebelumnya, apabila strategi ini diimplementasikan dengan baik dan sesuai maka tidak menutup kemungkinan akan memberikan hasil yang baik pula.

\section{d. Struktur Birokrasi}

Struktur birokrasi yang terdapat pada pengembangan Kampung Flory sebagai tempat wisata yang mampu meningkatkan perekonomian masyarakat desa dilangsungkan oleh beberapa aktor, termasuk oleh pihak pemerintah, mulai dari Pemerintah Pusat, Pemerintah Daerah, Sampai Pemerintah Desa. Pemerintah memiliki peran penting dalam pengembangan Kampung Flory sebagai tempat wisata yang menghasilkan pendapatan bagi masyarakat sekitar sebab memiliki peran sebagai pembentuk rencana, pemutusan kebijakan wisata, pihak promotor, dan mengatur pengunjungan yang dilaksanakan oleh wisatawan. Sebagai pihak yang turut serta dalam mengembangkan Kampung Flory, Dinas Pariwisata juga 
telah memfokuskan Kampung Flory agar diberdayakan sebagai suatu sektor riil sebab telah mencapai peningkatan anggaran desa seperti yang terdapat pada laman resmi DPR RI yang menjelaskan jika Kampung Flory menjadi desa percontohan akibat kemandirian dalam pengelolaan sumber daya alam dan manusia sehingga mencapai omset Rp 8.000.000.000 per tahun. Dengan besarnya omset tersebut, Pemerintah melalui Tim Kunjungan Kerja DPR RI Komisi XI melakukan persetujuan anggaran sejumlah Rp 470.13 Miliar dalam Program Sosial Bank Indonesia terhadap Kampung Flory.

Wisata Kampung Flory yang berlokasi di desa juga tidak luput dari adanya peran Pemerintah Desa setempat sebagai pihak yang membantu pengelola untuk meningkatkan perkembangan wisata dari segi daya tarik, fasilitas, sarana dan prasarana, serta masyarakat lokal yang mengelola wisata tersebut. Dikarenakan Kampung Flory berdiri pada tanah kas desa, maka dari itu Pemerintah Desa juga memiliki andil untuk mengarahkan perkembangan wisata Kampung Flory agar mendapatkan pembinaan yang lebih baik lagi. Adanya kerjasama yang dilaksanakan oleh Pemerintah Desa setempat dengan Pemerintah DIY mengenai pengelolaan Kampung Flory mengakibatkan pihak Bank Indonesia turut berpartisipasi dalam pengembangan Kampung Flory dari segi pelaksanaan Program Sosial Bank Indonesia dan Gerakan Nasional Non Tunai yang diprakarsai oleh beberapa bank, yakni BNI, BRI, Mandiri, dan BPD DIY.

Tujuan dari pengadaan program tersebut ialah sebagai wujud pemerintah dalam memberikan otoritas pada UMKM dalam menyelenggarakan kegiatan perekonomiannya serta wujud pemenuhan fasilitas pengunjung terhadap Kampung Flory. Menurut Pemerintah DIY dalam artikel "Bank Indonesia Wujudkan Smart City di Desa Wisata Kampung Flory" yang termuat di laman resmi Smart City Indo, kerjasama antara Kampung Flory dengan Bank Indonesia ialah bentuk penerapan Smart City di tempat wisata, sebab dengan pembayaran non tunai, akan memudahkan pengunjung ketika berwisata serta memanfaatkan teknologi bagi pengelola Kampung Flory, sehingga selain memperoleh pendapatan, pihak pengelola juga memperoleh pengetahuan sekaligus pengalaman melalui pemanfaatan teknologi dibidang wisata ekonomi kreatif. 


\section{Pengaruh Implementasi Kampung Flory terhadap Pendapatan Masyarakat Desa.}

\section{a. Gaji dan Upah}

Gaji serta upah yang diterima masyarakat selaku pengelola Kampung Flory diketahui sudah memenuhi standar upah kerja di daerah tersebut. Gaji serta upah yang didapatkan oleh masyarakat ini berasal dari pembayaran retribusi wisata Kampung Flory yang dibayarkan oleh pengunjung. Pengunjung memiliki peran penting dalam pendapatan masyarakat yang bekerja di Kampung Flory, sebab sebagian dana dari pengunjung akan disalurkan kepada pengelola, yakni masyarakat setempat sekitar 20 persen diperuntukkan kepada pengelola zona, 15 persen untuk pelaksana kegiatan di Kampung Flory, dan 25 persen untuk tabungan pekerja lokal.

Pengaruh implementasi Kampung Flory terhadap pendapatan masyarakat juga memberikan dampak berupa penyediaan lapangan kerja bagi masyarakat sekitar sebagai bagian dari pengelola, sehingga mereka memperoleh pemasukan dari mengelola wisata Kampung Flory. Masyarakat sekitar juga mampu mengembangkan UMKM di Kampung Flory melalui penjualan oleh-oleh dan tanaman hias di tempat wisata yang dilaksanakan oleh 4 (empat) dusun dan mampu mengasilkan omset sekitar Rp 8.000.000.000 ditahun 2019. Selain itu, masyarakat juga memperoleh bantuan sembako di hari raya sebagai salah satu bentuk upah tambahan mereka dalam mengelola Kampung Flory sebagai tempat wisata (Sumber: Hasil wawancara peneliti dengan pihak pengelola Kampung Flory).

\section{b. Sewa}

Sewa berkaitan dengan biaya yang harus dikeluarkan pengelola kepada desa, dikarenakan Kampung Flory berdiri di atas tanah kas Desa Tridadi, maka pihak pengelola Kampung Flory harus membayar biaya sewa sebesar Rp 20.000.000 pertahun sebagai pemasukan desa untuk disalurkan pada UMKM atau lingkungan sekitar Kampung Flory, pembangunan desa, ataupun dana pengembangan. Adanya penyewaan lahan yang masuk ke kas Desa Tridadi dapat meningkatkan pendapatan desa, seperti yang tertuang dalam laman resmi Badan Pemeriksa Keuangan RI pada suatu artikel online yang berjudul "Sewakan TKD 
Untuk Pendapatan Desa" yang menjelaskan tentang Peraturan Gubernur DIY Nomor 34 Tahun 2017 mengenai pemanfaatan tanah desa sebagai peluang wisata serta pemasukan yang diterima pihak pariwisata Kampung Flory. Pada konteks pendapatan masyarakat, maka indikator sewa telah terlaksana dengan baik dan administratif, sebab pihak pengelola Kampung Flory telah melakukan upaya sewa tanah kas desa.

Dari analisis data diatas, maka dapat diketahui bahwa implementasi program Desa Wisata Kampung Flory dilaksanakan dengan baik, hal ini dapat dilihat dari beberapa indikator implementasi yaitu, pertama komunikasi, dimana pengelola Kampung Flory berupaya untuk melakukan komunikasi dengan cara memasarkan dan mempromosikan keberadaan Kampung Flory agar menarik wisatawan lebih banyak lagi, yang kemudian akan berpengaruh pada pendapatan masyarakat dan desa. Kedua, sumber daya yaitu melalui tenaga kerja dan pengembangan tempat wisata. Kampung Flory sendiri dikelola dan dikembangkan oleh masyarakat di sekitar Kampung Flory, yang secara tidak langsung akan membantu masyarakat secara ekonomi melalui peningkatan pendapatan. Pengelola juga berupaya untuk terus mengembangkan Kampung Flory melalui penyediaan paket wisata dan berbagai fasilitas berupa sarana dan prasarana pendukung, sehingga dapat menjadi nilai tambah untuk menarik wisatawan. Ketiga, disposisi melalui penyediaan destinasi wisata oleh pihak pengelola dan adanya tindakan lain melalui pembentukan UMKM dan Koperasi untuk mendukung keberadaan objekobjek wisata di Kampung Flory. Keempat, struktur birokrasi yang juga berperan penting dalam implementasi program di Kampung Flory, mulai dari Pemerintah Pusat, Pemerintah Daerah, sampai Pemerintah Desa. Masing-masing pihak memiliki peran dalam mendukung keberhasilan dan pengembangan Kampung Flory.

Keberhasilan implementasi Kampung Flory kemudian berpengaruh pada pendapatan masyarakat desa di sekitar Kampung Flory. Hal ini terjadi karena semakin berkembangnya sebuah wisata (dalam hal ini Kampung Flory) berarti semakin banyak pula wisatawan yang akan datang mengunjungi tempat wisata tersebut, yang kemudian akan berpengaruh pada peningkatan pendapatan, baik 
pendapatan pengelola, masyarakat maupun desa itu sendiri. Peningkatan pendapatan masyarakat dapat dilihat dari gaji dan upah yang diterima, omset dari mengelola UMKM, serta bantuan sembako yang diberikan sebagai upah diluar gaji.

\section{Kesimpulan}

Jika dilihat dari hasil analisis terhadap indikator Implementasi Kampung Flory, maka dapat disimpulkan bahwa Kampung Flory dikelola dan diimplementasikan dengan baik, serta berpengaruh pada peningkatan pendapatan masyarakat. Pengaruh ini disebabkan oleh pengadaan Kampung Flory yang memiliki tujuan pemanfaatan lahan dan potensi desa dengan memanfaatkan komoditas unggulan Desa Tridadi melalui pengikutsertaan SDM menjadi pelaku usaha agar dapat memberikan kesejahteraan bagi masyarakat sekitar. Dari beberapa analisis mengenai implementasi Kampung Flory terhadap pendapatan masyarakat desa, maka peneliti menemukan beberapa faktor utama yang mempengaruhi, yaitu: 1) Adanya sumber daya yang dijadikan sebagai potensi pariwisata, 2) Partisipasi masyarakat sebagai wujud daya tanggap untuk mengelola wilayah mereka menjadi lapangan usaha sehingga mampu meningkatkan perekonomiannya, dan 3) Adanya stakeholder dan pemerintah, mulai dari pemerintah pusat, daerah dan desa yang ikut berperan dalam struktur birokrasi untuk meningkatkan pariwisata menjadi ekonomi kreatif.

Dari keberhasilan implementasi dan pengaruhnya pada peningkatan pendapatan masyarakat desa, perlu dilakukan peningkatan pada pemasaran dan promosi wisata Kampung Flory melalui pemanfaatan media sosial sebagai media promosi, mengingat penggunaan media sosial yang semakin meningkat serta penyebaran informasi yang semakin cepat dan meluas, sehingga wisata Kampung Flory dapat dikenal lebih luas dan dapat menarik lebih banyak wisatawan untuk berkunjung, yang kemudian akan semakin meningkatkan pendapatan masyarakat desa. 


\section{Referensi}

Atmoko, T. P. H. (2014). Strategi Pengembangan Potensi Desa Wisata Brajan Kabupaten Sleman. Jurnal Media Wisata, 12(2), 146-154.

Dritasto, A., \& Anggraeni, A. A. (2013). Analisis Dampak Ekonomi Wisata Bahari. Reka Loka, $\mathrm{xx}(\mathrm{x}), 1-8$.

Ekp, A. G., Unsyiah, F. E. B., Darussalam, K., Aceh, B., Covid, P., \& Indonesia, D. I. (2020). Ekonomi dan Kebijakan Publik Indonesia. 7(1), 36-53.

Gumilang, G. S. (2016). Metode Penelitian Kualitatif Dalam Bidang Bimbingan dan Konseling. 2(2), 16.

Helmita, H., Sari, O. N., Julianti, N. T., \& Dwinata, J. (2021). Pengembangan Desa Wisata Berkonsep Smart Tourism Melalui Pemberdayaan Kompetensi Masyarakat Desa Pujorahayu. Gema: Jurnal Gentiaras Manajemen dan Akuntansi, 13(1), 37-49.

Hidayatulah, R. P., \& Riau, K. (2018). Analisis: Jurnal Studi Keislaman Islam dan Ideologi Dalam Pembangunan di Indonesia: Studi Terhadap Program Nawacita Bagi umat Islam. 18(2), 171-188.

Ilmu, F., \& Ratulangi, U. S. (2014). Peningkatan Pendapatan Masyarakat Melalui Program Pemberdayaan di Desa Lolah Ii Kecamatan Tombariri Kabupaten Minahasa. 1, 92-105.

Karyani, A. S. dan T. (2020). Potential and Development Strategy of Flory Kampung as Community Based. 27(April), 45-59.

Kusniawati, D., Islami, N. P., Setyaningrum, B., \& Prasetyawati, E. (2017). Pemberdayaan Masyarakat Berbasis Potensi Lokal Melalui Program Desa Wisata di Desa Bumiaji. 2(1), 15.

Moleong, L. J. (2017). Metode Penelitian Kualitatif (36th ed.). PT Remaja Rosdakarya.

Ni, R., Sri, M., \& Dewi, P. (2020). Dampak Pengembangan Agrowisata Terhadap Kehidupan Sosial Ekonomi Masyarakat Lokal Kampung Flory Sleman, Yogyakarta (the Impact of Agrotourism Development on the Social Economic Livelihoods of Local Community Kampung Flory Sleman, 
Yogyakarta). Journal of Tourism Destination and Attraction, 8(1), 2685-6026.

Pantai, D., Amuk, L., Antiga, D., Ata, A., \& Sukma, I. N. (2018). Pengembangan Produk Pariwisata Melalui Penerapan Prinsip-Prinsip Ekowisata Bahari. 6(2), 252-257.

Pastor, N. M. Z. (2019). Strategi Pengembangan Agrowisata Kampung Flory. 23(3), 2019.

Pertiwi, E. R. (2018). Persepsi pengunjung agrowisata erp sleman yogyakarta. September, 1-7.

Ramdani, Z., \& Karyani, T. (2020). Partisipasi Masyarakat Dalam Pengembangan Agrowisata Dan Dampaknya Terhadap Sosial Ekonomi Masyarakat. Pemikiran Masyarakat Ilmiah Berwawasan Agribisnis, 6(2), 675-689.

Rani, F. P., Kusuma, H. E., \& Ardhyanto, A. (2018). Pariwisata Pusaka: Destinasi Dan Motivasi Wisata Di Pusaka Saujana Imogiri Yogyakarta. Jurnal Planologi, 15(2), 149.

Setijawan, A. (2018). Pembangunan Pariwisata Berkelanjutan dalam Perspektif Sosial Ekonomi. Jurnal Planoearth, 3(1), 7.

Sinonsayang, K., \& Minahasa, K. (2018). Implementasi Pembangunan Infrastruktur Desa Dalam Penggunaan Dana Desa Tahun 2017 (Studi) Desa Ongkaw Ii Kecamatan Sinonsayang Kabupaten Minahasa Selatan. 1, 1-11.

Soleman, M., \& Noer, M. (2017). Nawacita Sebagai Strategi Khusus Jokowi Periode Oktober 2014-20 Oktober 2015 [Nawacita: Superior Strategy of Jokowi in October 2014-20 October 2015]. Jurnal Kajian Politik Dan Masalah Pembangunan, 13(1), 1961-1975.

Subandi. (2011). Deskripsi Kualitatif Sebagai Satu Metode Dalam Penelitian Pertunjukan. 11(2).

Sudirman, F. A., \& Rifai, R. (2021). Private Sector Contribution in Achieving the Sustainable Development Goals (SDGs) 7 in Kendari, Indonesia. International Journal of Qualitative Research, 1(1), 55-60. https://doi.org/10.47540/ijqr.v1i1.319 
Sudirman, F. A., Upe, A., \& La Ode Herman, F. T. S. (2021). Corporate Social Responsibility (CSR) Contribution to Achieve Sustainable Development Goals (SDGs) in Southeast Sulawesi. Proceedings of the 11th Annual International Conference on Industrial Engineering and Operations Management Singapor. http://www.ieomsociety.org/singapore2021/papers/616.pdf

Sukmadewi, N. P. R., Darma Putra, I. N., \& Suardana, I. W. (2019). Potensi Dan Pengembangan Desa Wisata Suranadi Di Kecamatan Narmada Kabupaten Lombok Barat. Jurnal Master Pariwisata (JUMPA), 05, 424. Sutiyono, O. (2008). Pemberdayaan Masyarakat Desa Dalam Pelaksanaan Program Desa Wisata Di Daerah Istimewa Yogyakarta. 19.

Widiyanto, D., Handoyo, J. P., \& Fajarwati, A. (2008). Pengembangan Pariwisata Perdesaan (Suatu Usulan Strategi Bagi Desa Wisata Ketingan). Jurnal Bumi Lestari, 8(2), 205-210.

Yasa, I. N. M., \& Bagiana, I. G. Y. S. (2015). Pengembagan Desa Wisata Terhadap Kesejahteraan Masyarakat Desa Panglipuran, Kecamatan Bangli, Kabupaten Bangli. E-Jurnal EP Unud, 9(6), 1836-1867. 